\title{
KAJIAN TENTANG KOTA BERKELANJUTAN DI INDONESIA (STUDI KASUS KOTA YOGYAKARTA)
}

\section{REVIEW ON SUSTAINABLE CITY IN INDONESIA (CASE STUDY OF YOGYAKARTA CITY)}

\author{
Wulfram I. Ervianto ${ }^{1}$ \\ ${ }^{1}$ Program Studi Teknik Sipil-Fakultas Teknik-Universitas Atma Jaya Yogyakarta \\ Alamat korespondensi : \\ e-mail: ervianto@mail.uajy.ac.id
}

\begin{abstract}
Sustainability issues have become popular, these are caused by a global warming phenomenon that may concern the survival of life on the Earth by marking the increasing Earth's average temperature caused by the greenhouse effect. The purpose of this study is to find out how the city of Yogyakarta accomodates the principles of eco-friendly approaches. The using of research methodology is based on qualitative approaches by interpreting of secondary data. Several achievements of sustainability which are (a) The increasing of Yogyakarta's temperature and humidity is relatively high, one of the effect is the lack of green open spaces, $\pm 17,98 \%$. (b) In the case of air pollution issues indicate the level of carbon dioxide is 559.54 ppm exceeding the threshold applied by World Bank (381 PPM). (c) The inequality of income distribution indicates at the moderate imbalance (0,51). The result of this study are as follows : (a) To implement the concept of sustainable city. (b) To evaluate the environmental impact assessments for infrastructure in Yogyakarta. (c) To Issuie mayoral regulations requiring every infrastructure must have facility for treating hazardous and toxic waste materials independently and reporting periodic and routine audit results. (d) To develop appropriate technology for the processing of wastewater at the village level in order to be used for other purposes. (e) To enable economic activity at the village situation.
\end{abstract}

Keywords: Study, Sustainable City, Indonesia

\begin{abstract}
Abstrak
Isu keberlanjutan menjadi populer, pemicunya adalah fenomena pemanasan global yang mengkawatirkan keberlangsungan kehidupan di Bumi. Gejalanya adalah meningkatnya suhu rata-rata di Bumi yang disebabkan oleh efek gas rumah kaca. Tujuan kajian adalah untuk mengetahui capaian kota Yogyakarta telah mengakomodasi prinsip ramah lingkungan. Metodologi penelitian yang digunakan didasarkan pada pendekatan kualitatif melalui interpertasi data sekunder yang tersedia dan dapat diakses oleh umum. Beberapa capaian keberlanjutan di kota Yogyakarta adalah: (a) Suhu dan kelembaban kota Yogyakarta mengalami peningkatan relatif tinggi, disebabkan karena terbatasnya ruang terbuka hijau, yaitu $\pm 17,98 \%$. (b) Pencemaran udara, kadar $\mathrm{CO}_{2}$ sebesar $\pm 559,54$ PPM melebihi ambang batas yang ditetapkan oleh World Bank, yaitu 381 PPM. (c) Rasio gini pada ketimpangan moderat $(0,451)$. Hasil kajian adalah : (a) Mengimplementasikan konsep kota berkelanjutan secara lengkap dan benar. (b) Mengevaluasi analisis dampak lingkungan untuk hotel, pusat perbelanjaan, dan fasilitas kesehatan di kota Yogyakarta. (c) Menerbitkan peraturan walikota yang mewajibkan setiap hotel, pusat perbelanjaan, dan fasilitas kesehatan memiliki fasilitas pengolahan limbah bahan berbahaya dan beracun secara mandiri dan melaporkan hasil audit secara berkala dan rutin. (d) Mengembangkan teknologi tepat guna untuk pengolahan limbah cair di tingkat kampung. (e) Menghidupkan aktivitas ekonomi di tingkat kampung.
\end{abstract}

Kata kunci: Kajian, Kota Berkelanjutan, Indonesia.

\section{PENDAHULUAN}

Kota merupakan wadah bagi banyak orang sebagai tempat untuk menjalani kehidupan, beraktivitas dan merupakan pusat perjuangan keras manusia. Selain itu, kota juga sebagai pusat kreativitas dan budaya yang melambangkan kemajuan sosial dan ekonomi. Definisi kota dapat ditinjau dari beberapa perspektif yang berbeda. Pendekatan pertama, didasarkan pada 
morfologi kota dan yang kedua berdasarkan pendekatan legal/yuridis administratif. Pengertian kota dapat didekati berdasarkan enam perspektif, yaitu: (a) pendekatan yuridis administratif; (b) pendekatan fisik morfologis; (c) pendekatan jumlah penduduk; (d) pendekatan kepadatan penduduk; (e) pendekatan fungsi dalam wilayah; (f) pendekatan sosial-ekonomi (Yunus, H.S., 2015).

Berbagai pendekatan dapat digunakan untuk memahami sebuah kota, diantaranya adalah telah dipublikasikannya isu tentang kota hijau dan kota berkelanjutan yang sesungguhnya merupakan agregasi dari enam pendekatan tersebut diatas, ditambah dengan pendekatan isu lingkungan. Pendekatan kota hijau dan berkelanjutan perlu dilakukan secara simultan antara kota satu dengan kota lainnya mengingat infrastrukturnya saling terintegrasi.

Berdasarkan data yang terkait dengan komposisi penduduk yang tinggal di pedesaan dan perkotaan merupakan informasi penting karena peran pedesaan akan tereduksi khususnya sebagai penyangga pangan nasional (gambar 1). Urbanisasi yang tidak direncanakan secara baik akan berpotensi menimbulkan berbagai persoalan di perkotaan, seperti polusi, perluasan kawasan kumuh, berkurangnya suplai komoditas penting bagi perkotaan, seperti air, pangan dan energi. Dampak jangka panjang akibat urbanisasi adalah kesenjangan antar wilayah, antar kota, dan antara desa dan kota.

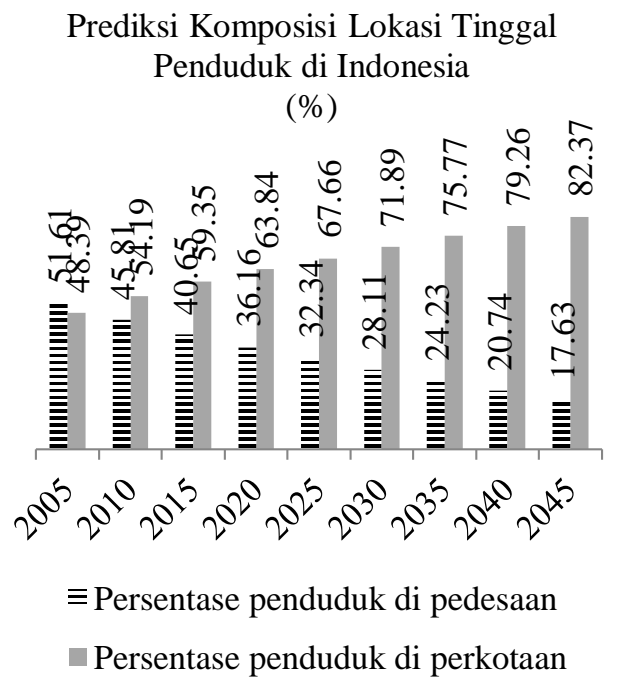

Gambar 1. Komposisi Tempat Tinggal Penduduk Saat Ini dan Prediksi Mendatang
Di tingkat nasional Indonesia, hal ini direspon positif oleh pemerintahan saat ini dengan memprogramkan pembangunan dari pinggiran sesuai dengan poin ketiga dalam Nawacita dan dokumen RPJMN 2015-2019 yang disusun oleh Bappenas. Selain itu, kebijakan desentralisasi asimetris (dimana setiap daerah tidak harus sama dalam mendapatkan anggaran pembangunan) yang diterapkan oleh pemerintah sangat relevan dengan kondisi eksisting wilayah Indonesia yang bertujuan untuk melindungi kepentingan nasional Indonesia di kawasan perbatasan, memperkuat daya saing ekonomi Indonesia secara global, dan untuk membantu daerah yang kapasitas berpemerintahannya belum cukup memadai dalam memberikan pelayanan publik.

Tujuan penelitian ini adalah untuk mengetahui berbagai hal yang telah dicapai oleh pemerintah kota Yogyakarta dalam perspektif kota berkelanjutan didasarkan data yang tersedia ditambah knowledge yang telah dipublikasikan. Hasil kajian ini diharapkan dapat bermanfaat bagi pemerintah kota, sekaligus bagi peneliti lain yang fokus pada pengembangan kota berkelanjutan untuk pengembangan daerah lain di Indonesia.

Kota berkelanjutan dapat diartikan kota yang mampu bertahan akibat tekanan perubahan ekonomi, lingkungan, sosial dan budaya. Salah satu tantangannya adalah menciptakan keberlanjutan sistem politik, dan kelembagaan berikut strategi, program, dan kebijakan sehingga pembangunan kota yang berkelanjutan dapat terwujud dan menjadikan kota yang nyaman bagi warganya.

United Nation Habitat mendefinisikan kota berkelanjutan adalah kota yang dalam pembangunan di bidang sosial, ekonomi dan fisiknya dilakukan untuk jangka waktu yang lama. "Artinya dalam pembangunan kota tersebut memiliki pasokan sumber daya alam yang terus menerus dengan memperhatikan daya dukung, daya tampung serta kelestariannya,"

Dalam dokumen the world commision on environment and development yang dipublikasikan tahun 1997 dinyatakan bahwa wujud kota berkelanjutan mencakup berbagai hal sebagai berikut: (a) Dibangun dengan kepedulian dan memperhatikan aset lingkungan alam, memperhatikan penggunaan sumber daya, meminimalisasi 
dampak negatif kegiatan terhadap alam. (b) Kota berkelanjutan berada pada tatanan regional dan global, tidak peduli apakah besar atau kecil, tanggung jawabnya melewati batas-batas kota. (c) Meliputi areal yang lebih luas, dimana individu bertanggung jawab terhadap kota. (d) Memerlukan asetaset lingkungan dan dampaknya terdistribusi secara lebih merata. (e) Kota berkelanjutan adalah kota pengetahuan, kota bersama, kota dengan jaringan internasional. (f) Memperhatikan konservasi, memperkuat dan mengedepankan hal-hal yang berkaitan dengan alam dan lingkungan. (g) Memiliki lebih banyak kesempatan untuk memperkuat kualitas lingkungan skala lokal, regional, dan global.

United Nation Habitat mendefinisikan kota berkelanjutan adalah kota yang pembangunan di bidang sosial, ekonomi dan fisiknya dilakukan untuk jangka waktu yang lama. Artinya dalam pembangunan kota berkelanjutan memiliki pasokan sumber daya alam yang terus menerus dengan memperhatikan daya dukung, daya tampung dan kelestariannya. Di tingkat nasional, Kementerian Percepatan Pembangunan Nasional/Bappenas pada tahun 2011 mempublikasikan Indeks Kota Berkelanjutan (IKB) yang didasarkan pada tipologi kota di Indonesia yang mencakup enam aspek, yaitu: Sistem Pelayanan Perkotaan, Sosial Budaya, Ekonomi, Lingkungan, Tata Kelola Kota, Sistem Perkotaan Nasional (Tabel 1). Sedangkan Key Performance Indikator pembangunan kota berkelanjutan mencakup tiga pilar, yaitu: Pilar ekonomi, Pilar sosial, Pilar lingkungan (Apriyanto, H., dkk) (gambar 2).

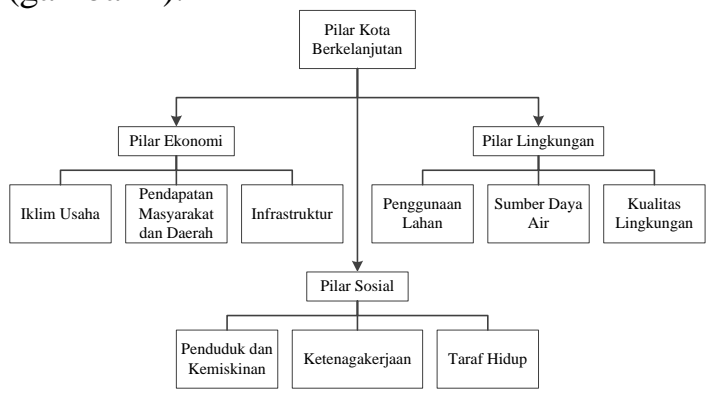

Gambar 2. Tiga Pilar Kota Berkelanjutan

Tabel 1. Indeks Kota Berkelanjutan

\begin{tabular}{|c|c|c|c|c|c|c|c|}
\hline 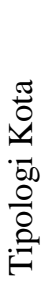 & 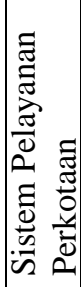 & 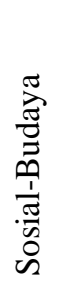 & $\begin{array}{l}\cdot \bar{\Xi} \\
\overline{0} \\
\frac{0}{I}\end{array}$ & 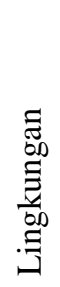 & 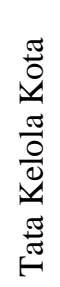 & 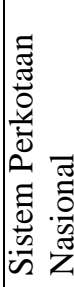 & 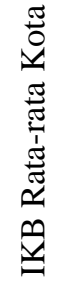 \\
\hline A & $\begin{array}{l}\infty \\
\vec{n}\end{array}$ & $\begin{array}{l}\hat{n} \\
\text { ô }\end{array}$ & $\begin{array}{l}\text { O } \\
\text { a } \\
\text { N }\end{array}$ & $\begin{array}{l}8 \\
\infty \\
i n\end{array}$ & $\begin{array}{l}\text { bे } \\
\text { if }\end{array}$ & $\begin{array}{l}n \\
\infty \\
\infty \\
尺\end{array}$ & $\begin{array}{l}\text { Jे } \\
\text { in }\end{array}$ \\
\hline B & $\begin{array}{l}+ \\
\text { n. } \\
\text { ñ }\end{array}$ & $\begin{array}{l}\text { q+ } \\
\text { of }\end{array}$ & $\frac{ \pm}{\stackrel{\infty}{+}}$ & 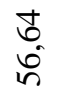 & 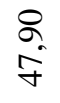 & $\begin{array}{l}8 \\
8 \\
8\end{array}$ & \begin{tabular}{l}
$\stackrel{m}{2}$ \\
\multirow{\gamma}{*}{}
\end{tabular} \\
\hline $\mathrm{C}$ & $\begin{array}{l}\tilde{n} \\
\text { r }\end{array}$ & $\begin{array}{l}\stackrel{0}{\circ} \\
\text { กิ }\end{array}$ & $\begin{array}{l}\text { oे } \\
\text { के } \\
\text { in }\end{array}$ & $\begin{array}{l}\dot{0} \\
8\end{array}$ & $\frac{\vec{F}}{\dot{F}}$ & $\frac{\partial}{\vec{n}}$ & $\frac{\infty}{n}$ \\
\hline D & $\begin{array}{l}\text { ָे } \\
\text { }\end{array}$ & $\begin{array}{l}m \\
\infty \\
\infty \\
n\end{array}$ & $\begin{array}{l}\text { Do } \\
\stackrel{i}{d}\end{array}$ & $\begin{array}{l}\hat{\text { }} \\
\text { }\end{array}$ & $\begin{array}{l}\text { ले } \\
\text { ले }\end{array}$ & $\frac{n}{\xi}$ & $\begin{array}{l}\bar{y} \\
\dot{f}\end{array}$ \\
\hline E & $\begin{array}{l}\hat{A} \\
\stackrel{\infty}{+}\end{array}$ & $\begin{array}{l}\hat{n} \\
\hat{q}\end{array}$ & $\frac{\mathfrak{N}}{\stackrel{\sim}{f}}$ & $\begin{array}{l}\text { iे } \\
\text { in } \\
\text { in }\end{array}$ & $\begin{array}{l}\bar{\sigma} \\
\dot{f}\end{array}$ & $\underset{i}{\stackrel{+}{i}}$ & $\begin{array}{l}m \\
m \\
o \\
q\end{array}$ \\
\hline
\end{tabular}

Sumber: Kementerian Percepatan Pembangunan Nasional/Bappenas (2011).

Catatan:

A : Metropolitan; B : Besar; C : Sedang; D : Kecil;

$\mathrm{E}:$ Seluruh kota.

Dalam pilar ekonomi, mencakup tiga elemen yaitu: Pertama, elemen iklim usaha, yang terdiri dari dua indikator, yaitu laju nilai investasi dan institusi pelayanan perijinan. Kedua, elemen pendapatan masyarakat dan daerah, yang terdiri dari dua indikator, yaitu: Produk Domestik Regional Bruto (PDRB) per kapita dan Kontribusi Pendapatan Asli Daerah (PAD) dalam total pendapatan daerah. Ketiga, elemen infrastruktur, yang terdiri dari yaitu : kualitas dan aksesibilitas jalan. dan akses air, sanitasi, listrik, dan telepon.

Dalam pilar lingkungan, mencakup tiga elemen yaitu: Pertama, elemen penggunaan lahan, yang terdiri dari tiga indikator, yaitu : penutupan lahan, kawasan lindung, dan ruang terbuka hijau kawasan perkotaan. Kedua, elemen sumber daya air, terdiri dari dua indikator, yaitu : keseimbangan air, dan kualitas air. Ketiga, elemen kualitas lingkungan, terdiri dari dua indikator, yaitu: persampahan dan kualitas udara.

Dalam pilar sosial, mencakup tiga elemen, yaitu : pertama, elemen penduduk dan kemiskinan yang terdiri dari tiga indikator, yaitu pertumbuhan penduduk, jumlah penduduk dibawah garis kemiskinan, 
dan kesenjangan pendapatan. Kedua, elemen ketenagakerjaan yang terdiri dari dua indikator, yaitu tingkat kesempatan kerja dan tingkat pengangguran. Ketiga, elemen taraf hidup, yang terdiri dari dua indikator, yaitu Indeks Pembangunan Manusia (IPM) dan jumlah tindakan kriminal.

\section{METODE PENELITIAN}

Pendekatan yang digunakan dalam studi ini didasarkan pada data sekunder yang tersedia untuk umum/publik yang bersumber dari hasil penelitian maupun dokumen resmi lain yang telah dipublikasikan. Obyek studi adalah kota Yogyakarta yang didekati dengan besaran kota berkelanjutan yang telah diformulasikan oleh Apriyanto.

\section{Profil Kota Yogyakarta}

Berdasarkan data tahun 2016, kota Yogyakarta mempunyai luas wilayah 32,5 $\mathrm{km}^{2}$ dengan kepadatan penduduk $12.699 / \mathrm{km}^{2}$. Angka ini mengalami peningkatan jika dibandingkan dengan data kepadatan penduduk dalam lima tahun terakhir sebesar $12.077 / \mathrm{km}^{2} \quad(\approx 124 /$ tahun $)$. Tentu persoalan ini akan berpengaruh terhadap keseimbangan sumberdaya yang tersedia dalam wilayah tersebut. Pada umumnya, persoalan kota terkait erat dengan berbagai hal sebagai berikut : migrasi penduduk, kesehatan, birokrasi, transportasi, sampah, komunikasi, air, dan pemanasan global. Setiap persoalan tersebut saling terkait satu sama lain, sehingga perlu ketepatan dalam penyelesaiannya.

\section{Persoalan Lingkungan}

Salah satu isu penting yang perlu segera direspon adalah persoalan ketersediaan air terutama air bersih, mengingat telah terjadi fenomena penurunan muka air tanah yang diduga kuat akibat aktivitas pembangunan infrastruktur, seperti hotel, pusat perbelanjaan dan lainnya. Setiap tahun, air tanah di kota Yogyakarta mengalami penurunan $\pm 30 \mathrm{~cm}$ yang diikuti dengan bertambahnya jumlah sumur yang mengering. Selain itu, luas daerah resapan air mengalami penurunan sebesar $\pm 20 \%$ akibat perubahan ruang terbuka hijau menjadi tempat pemukiman (Purwantara, S., 2015). Untuk mewujudkan kota Yogyakarta sebagai kota layak huni dalam perspektif lingkungan, masih dibutuhkan Ruang Terbuka Hijau
(RTH) minimal seluas 390,62 hektar guna memenuhi RTH minimum sebesar 30\% dari luas wilayah kota Yogyakarta $(\approx 975$ hektar).

RTH kota Yogyakarta saat ini tergolong relatif kecil, yaitu sebesar 584,38 hektar $(\approx 17,98 \%)$ dari luas total wilayah kota Yogyakarta yang terdiri dari RTH publik seluas 329,58 hektar $(\approx 10,14 \%)$ dan $\mathrm{RTH}$ privat seluas 254,80 hektar $(\approx 7,84 \%)$ (Ratnasari, A.,dkk., 2015). Akibat capaian RTH yang relatif kecil tersebut, maka berdampak pada meningkatnya suhu dan kelembaban udara kota Yogyakarta yang relatif tinggi. Ditambah lagi persoalan tingkat pencemaran udara yang relatif cukup tinggi yang ditunjukkan oleh kadar $\mathrm{CO}_{2}$ sebesar 559,54 Part Per Million (PPM) dan telah melebihi ambang batas yang ditetapkan oleh World Bank sebesar 381 PPM (Astuti dkk., 2013).

\section{Persoalan Ekonomi}

Persoalan ekonomi kota Yogyakarta khususnya distribusi pendapatan warga Yogyakarta dalam kategori moderat/sedang yang ditunjukan oleh indeks gini sebesar 0,4151 sesuai data Badan Pusat Statistik (BPS) (Gambar 3.) Semakin besar indeks gini dapat diartikan semakin besar ketimpangan pendapatan penduduk di kota Yogyakarta yang terkait erat dengan kemiskinan. Persentase penduduk miskin di Kota Yogyakarta bulan September tahun 2014 berada pada posisi terendah jika dibandingkan dengan kabupaten lain di Daerah Istimewa Yogyakarta.

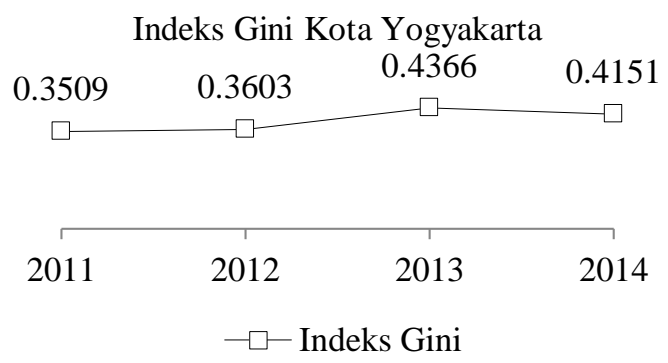

Gambar 3. Indeks Gini Kota Yogyakarta

Perekonomian Kota Yogyakarta secara umum ditopang oleh sektor jasa khususnya sektor pendidikan dan sektor pariwisata serta industri yang berkaitan dengan kedua sektor tersebut. Laju pertumbuhan ekonomi Kota Yogyakarta pada tahun 2015 yang dihitung 
berdasarkan Produk Domestik Regional Bruto atas dasar harga konstan 2010 mencapai $5,16 \%$, sedikit lebih rendah dibandingkan laju pertumbuhan ekonomi pada tahun 2014 yang mencapai 5,30\%.

Sektor ekonomi yang mengalami pertumbuhan paling cepat adalah lapangan usaha jasa keuangan dan asuransi sebesar $7,75 \%$, diikuti oleh jasa kesehatan dan kegiatan sosial sebesar 7,39\%, dan jasa perusahaan sebesar 7,20\% (BPS Kota Yogyakarta, 2016).

Perekonomian Kota Yogyakarta juga relatif stabil dengan tingkat inflasi pada tahun 2015 sebesar 3,09\%. Inflasi tahun 2015 lebih rendah dibandingkan dengan inflasi pada tahun 2014 yang sebesar 6,59\% (BPS Kota Yogyakarta, 2016). Penyumbang inflasi tertinggi tahun 2015 adalah sektor sandang sebesar $5,87 \%$ sementara sektor transportasi memberikan sumbangan terendah sebesar 2,51\% (BPS Kota Yogyakarta, 2016). Bulan Desember 2015 menjadi bulan dengan inflasi tertinggi sebesar $0,96 \%$ yang disebabkan karena terjadinya kenaikan harga bahan makanan saat natal dan tahun baru serta naiknya tarif listrik (BPS Kota Yogyakarta, 2016).

\section{Persoalan Sosial}

Pertumbuhan penduduk perkotaan di Indonesia mencapai $\pm 2.75 \%$ per tahun, dimana nilai tersebut lebih tinggi dari laju pertumbuhan penduduk nasional sebesar \pm $1.17 \%$ per tahun. Jika hal ini digunakan untuk memproyeksikan jumlah penduduk Indonesia yang tinggal di perkotaan, maka di tahun 2045 jumlah penduduk yang tinggal di perkotaan akan mencapai $\pm 82,37 \%$ dan sisanya adalah penduduk yang tinggal di pedesaan dimana jumlahnya kurang dari 20 $\%$ (gambar 1).

Tingkat pengangguran kota Yogyakarta cenderung mengalami penurunan sejak tahun 2010, namun sempat meningkat di tahun 2013 dan selanjutnya mengalami penurunan hingga tahun 2015 (gambar 4). Semakin tinggi Tingkat Partisipasi Angkatan Kerja (TPAK) menunjukan bahwa semakin tinggi pasokan tenaga kerja (labour supply) yang tersedia untuk memproduksi barang dan jasa dalam suatu perekonomian (gambar 5).

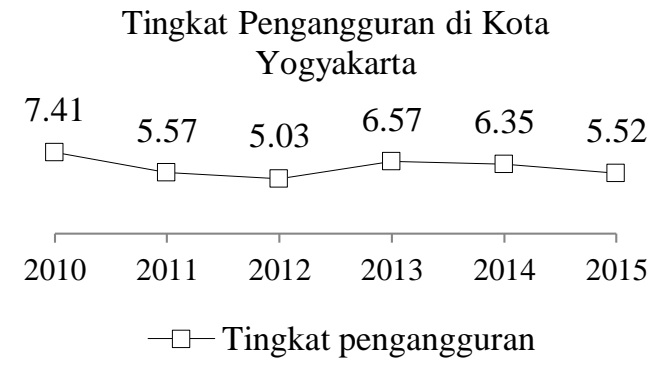

Gambar 4. Tingkat Pengangguran di Kota Yogyakarta.

Partisipasi Angkatan Kerja Kota Yogyakarta

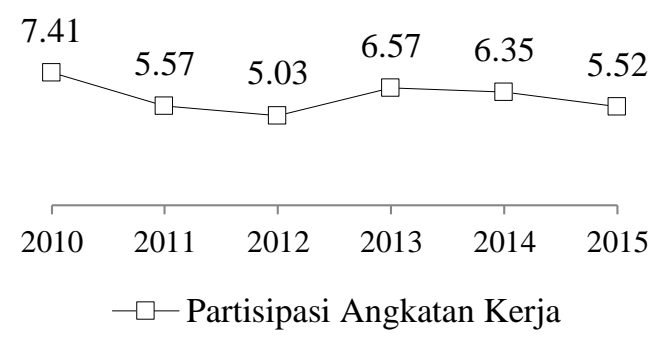

Gambar 5. Partisipasi Angkatan Kerja

\section{KESIMPULAN}

Dalam melakukan kajian tentang Yogyakarta mencapai kota berkelanjutan terdapat beberapa hambatan terutama dalam memperoleh data yang terkait dengan indikator kota berkelanjutan. Namun demikian hasil kajian ini dirasakan cukup dapat memberikan gambaran mengenai halhal yang telah diimplementasikan di tingkat kota, meskipun masih perlu kajian yang lebih komprehensif untuk dapat memenuhi indikator yang telah ditetapkan sebagai hasil kajian Apriyanto secara kuantitaif.

Dalam perspektif lingkungan, beberapa indikator yang melebihi batas maksimum yang ditetapkan adalah : (1) Ruang Terbuka Hijau (RTH) yang tersedia masih relatif kecil sebagai dampak maraknya izin pembangunan bangunan gedung untuk hotel yang telah disetujui secara prinsip. Dampak negatif persoalan ini adalah tinggi muka air tanah di kota Yogyakarta telah mengalami penurunan sebagai dampak berkurangnya air hujan yang diinfiltrasikan yang berubah menjadi aliran permukaan. Dampak jangka panjang berupa krisis air bersih. (2) Dengan bertambahnya berbagai infrastruktur fisik di kota Yogyakarta membuka peluang pekerjaan 
bagi segenap warga Yogyakarta sesuai dengan tren menurunnya data tingkat pengangguran. (3) Saran untuk penelitian berikutnya adalah perlu melakukan wawancara langsung kepada pemangku kepentingan agar memperoleh data yang lebih komprehensif, mengingat terbatasnya data sekunder yang tersedia di ruang publik.

\section{DAFTAR PUSTAKA}

Apriyanto, H., 2015. Status Berkelanjutan Kota Tangerang Selatan-Banten Dengan Menggunakan Key Performance Indicators. Jurnal Manusia dan Lingkungan, Vol. 22, No.2, Juli 2015: 260-270.

Astuti, I., Agustina D., Firdaus, Thoha, dan Ishafit. Pemetaan Kandungan $\mathrm{CO}_{2}$ di Kota Yogyakarta Ditinjau dari Tingkat Keramaian Kendaraan Bermotor dan Kondisi Lingkungan. Seminar Nasional Quantum 2013. Program Studi Fisika FKIP Universitas Ahmad Dahlan Yogyakarta. ProsidinG: 2013.

Badan Pusat Statistik (BPS) Kota Yogyakarta, Statistik Kesejahteraan Rakyat Kota Yogyakarta, 2015.

Kementerian Percepatan Pembangunan Nasional/Bappenas, Indeks Kota Berkelanjutan Indonesia, 2011.

Purwantara, S. Dampak Pengembangan Pemukiman Terhadap Air Tanah di Wilayah Yogyakarta dan Sekitarnya. Geoedukasi. Volume IV Nomor 1. 2015.

Ratnasari, Amalia, Sitorus, Santun, R.P, Tjahjono, Boedi. Perencanaan Kota Hijau Yogyakarta Berdasarkan Penggunaan Lahan dan Kecukupan RTH. Tata Loka, Volume 17 Nomor 4. Biro Penerbit Planologi Undip: 2015.

World Commision on Environment and Development, 1997.

Yunus, H.S. Manajemen kota perspektif spasial. Pustaka Pelajar: 2015. 